\title{
Recovery of Bovine Embryos by Invented Cervical Mucus Remover and Ova Collector Dish
}

\author{
Tatsuyuki Suzuki, Shuichi Matsuda, Yutaka SAka and Takashi Ishida \\ Fukushima National Livestock Breeding Station, The Ministry of Agriculture, \\ Forestry and Fisheries, Nishishirakawa-gun, Fukushima 961
}

(Accepted for publication August 3, 1987)

\begin{abstract}
Summary. A newly deviced cervical mucus remover was tested to improve a method for removing the cervical mucus before flushing the embryos. The embryos were collected in a newly deviced collective dish.

The recovery rate of embryos was significantly higher with the new procedure than that with the cervical dilator. Namely, the number of embryos recovered were $12.05 \pm 7.86$ for the former vs $8.52 \pm 6.82$ for the latter $(\mathrm{P}<0.05)$. Five of 43 donors had flushing trouble when the cervical dilator was used for removing the cervical mucus. However, there was no trouble when the newly deviced cervical mucus remover was used for removing the mucus. KEY WORDS; BOVINE, FLUSHING, CERVICAL MUCUS REMOVER, COLLECTIVE DISH.
\end{abstract}

Jpn J Anim Reprod 33, 160-162, 1987

\section{子宮頸管粘液除去器と卵回収容器の併用による 効率的なウシ肧の回収法}

鈴木 達行・松田 修一・酒井豊・石田 隆志

農林水産省福島種畜牧場 961 福島県西白河郡西郷村小田倉

一般にウシ胚は受精後 $7 \sim 8$ 日目に非手術的な方法に より子宮を灌流して回収される。この時期の子宮頸管は 固く閉ざされ，粘着性の強い粘液で閉塞されている。し たがって, この状態で直ちに頸管拡張棒やカテーテルを 与综頸管内に插入すると糊状またはゼリ一状の粘着性の ある粘液を子宮内に押込むことになり，これが子宮灌流 将のカテーテル小孔の目ゔまりの原因となり, 胚回収を 妨げる。そこで筆者らは受精卵を回収する前に頸管粘液 を除去する目的で，先端から $10 \mathrm{~cm}$ の所まで直径 $2 \mathrm{~mm}$ 大の穴を18箇所開けたシリコン製の外筒部と内腔に密着 するスチール製内芯部とからなる器具を新しく考察し た。また，回収後の卵の検索を短時間で行うことを目的 に, 容器の周冊に $75 \mu \mathrm{m}$ のメッシュを付けた器具を試 作してウシ胚の回収に用いたところ, 従来の方法に比べ
てより短時間で回収でき，胚回収率の问上が認められた ので，その概要を報告する。

\section{材料と方法}

供試牛は福島種畜牧場繫養の $2 \sim 10$ 歳の黒毛和種䧳牛 81頭である。供卵牛には, 前回の発情から9〜14日後に 卵胞刺激ホルモン (FSH) 計 $24 \mathrm{AU}$ （デンカ製薬製 0.5 $\mathrm{AU} / \mathrm{ml}$ ) を朝夕 2 回に分けて 3 日間 $5 \cdot 5 \cdot 4 \cdot 4 \cdot 3 \cdot 3 \mathrm{AU}$ ずつ分割投与し，更にプロスタグランデイン (PG) $\mathrm{F}_{2} \alpha$ $15 \mathrm{mg}$ (アッジプョン製)を FSH 投与開始後 3 日目の朝, 昼，夕に，それぞれ $5 \mathrm{mg}$ ずつ分割投与した。次いで発 情の現われた日の午後と翌朝の 2 回凍結精液を使用して 人工授精を行った。黄体の形成数と未排卵卵胞数の推定 は胚回収の前日，または当日に直腸検査により行った。 

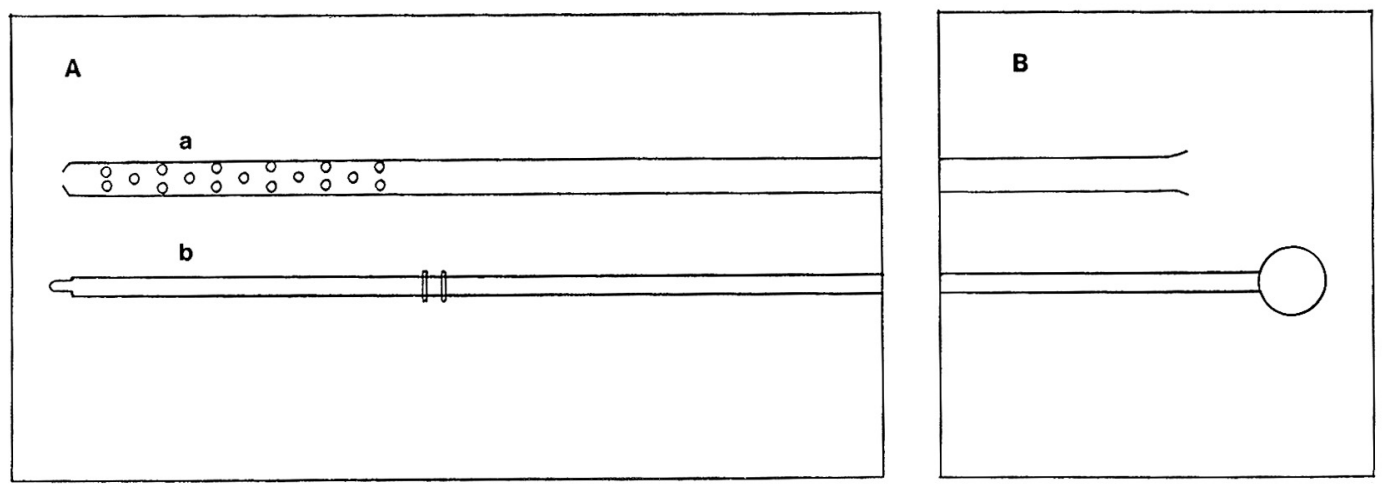

Fig. 1. Cervical mucus remover for removing the mucus from the cervix before flushing the ova in cattle.

$\mathrm{A}$ and B: The distal and proximal ends of cervical mucus remover.

(a) 18 holes $2 \mathrm{~mm}$ in diameter

(b) steel bar

(c) 2 rings for vacuum aspiration of the outer sheath

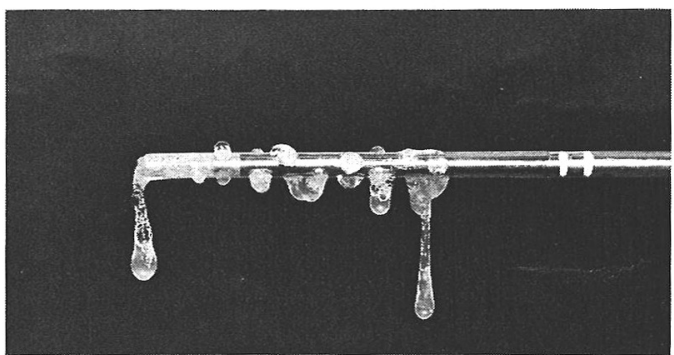

Fig. 2. A new cervical mucus remover after removing the mucus.

胚は過剩排卵処理により誘起された発情後 7 日目に回 収した。まず，頸管拡張棒あるいは新しく考案した子宮 頸管粘液除去器（Fig. 1) を用い，それぞれ43頭と38頭 について頸管抎張あるい怗液を除去したのち，既報 (鈴木ら, 1984; 鈴木と下平, 1986) の多孔式カテーテ ル（ニプロ製）と自動灌流器具（富士平製）を用いて, いずれも新しく考案した胚回収容器（Fig. 2) に灌流液 を集めた。

子宮頸管粘液除去器の構造け外筒部と内芯部とからな り, 外筒部け長さ $40 \mathrm{~cm}$, 直径 $6 \mathrm{~mm}$ のシリコン製で, その先端部と先端から $10 \mathrm{~cm}$ の所まで直径 $2 \mathrm{~mm}$ 大の 穴を18箅所開けてあり, 内芯部は直径 $4 \mathrm{~mm}$, 長さ 43 $\mathrm{cm}$ のスチール製で, 内芯部の先端から $15 \mathrm{~cm}$ の所に外 筒の内腔に密着するようにリングが付いている。使用時 には, 器具の先端が子宮頸管経由で子宮体へ到達した時 に, 内芯を約 $15 \mathrm{~cm}$ 程度引きながら器具全体を胵外へ

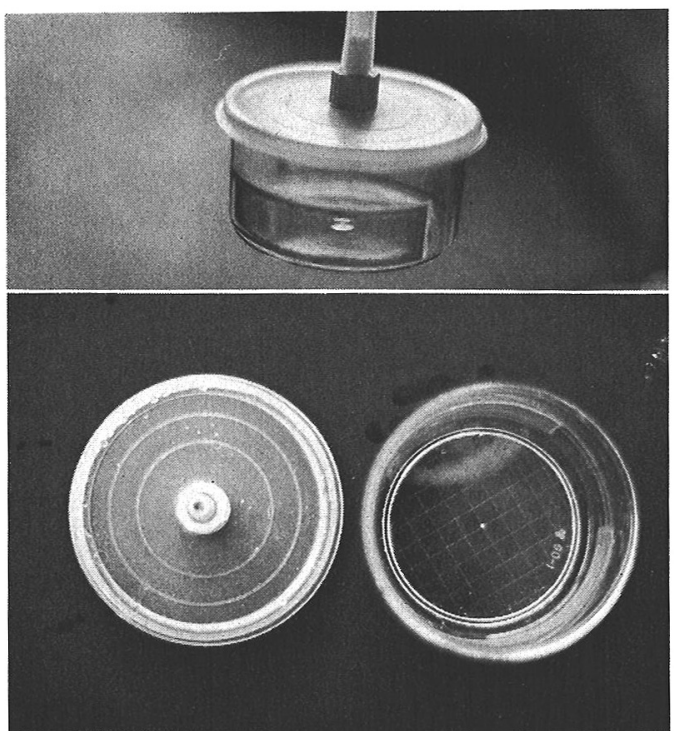

Fig. 3. A new collective dish for collecting the embryos.

取り出した。頸管捘張棒による子宮頸管の拡張は，先端 部が子宮体に到達したのち，数回回転させながら子宫頸 管を広げた後胵外へ抜去した。

胚の回収に用いた 容器は高さ $4.5 \mathrm{~cm}$, 直径 $8 \mathrm{~cm}$ の 円筒状で, 底から $1 \mathrm{~cm}$ の所から高さ $1.5 \mathrm{~cm}$, 幅 $7.5 \mathrm{~cm}$ の $75 \mu \mathrm{m}$ のメッシュ孝 2 箇所に張りつけ，取り外しの できるシリコン製の蓋の付いた構造になっている（Fig， 3)。灌流液には Wittingham's Modified Dulbecco's 
Table 1. The recovery of ova using the new cervical mucus remover and cervical dilator for removing the cervical mucus

\begin{tabular}{ccccc}
\hline $\begin{array}{l}\text { Used equipments for } \\
\text { removing the mucus }\end{array}$ & $\begin{array}{c}\text { No. of } \\
\text { donors }\end{array}$ & No. CL palpated & $\begin{array}{c}\text { No. of donors choked } \\
\text { with mucus }\end{array}$ & No. ova recovered \\
\hline $\begin{array}{l}\text { Cervical dilator } \\
\begin{array}{l}\text { Cervical mucus } \\
\text { remover }\end{array}\end{array}$ & 43 & $13.64 \pm 6.40$ & 5 & $8.52 \pm 6.8 \check{5}^{\mathrm{a}}$ \\
\hline
\end{tabular}

* Mean $\pm S E \quad$ a vs $b \quad P<0.05$

PBS（Whittingham，1971）を用い，左右子宮角を別々 にそれぞれ $300 \mathrm{ml}$ で灌流し, 直接メッシュ付回収容器 に灌流液を集め，実体顕微鏡下で胚を検索した。

\section{結果および考察}

頸管拡張棒とバルーンカテーテル，あるいは粘液除去 器とバルーンカテーテルを用いた場合の胚回収率は, そ れぞれ $75.5 \%$ と $87.9 \%$ となり後者で有意に高かった $(\mathrm{P}<0.05)$ 。推定黄体数は, 頸管拡張棒を使用した牛群 と粘液除去器を使用した牛群との比較では, それぞれ 13. $64 \pm 6.40$ (平均士標準偏差, 以下同様) と $13.93 \pm$ 6.85 となり両群間に有意な差異はなかったが，回収胚 数は $8.52 \pm 6.82$ と $12.05 \pm 7.86$ となり有意差 $(\mathrm{P}<$ 0.05）が浔められた。また，前者では泼回収時にバルー ンカテーテルに目づまりを生じ，取り換えを行った事例 が 5 例あったのに対し, 後者ではこのような事例はみら れなかった。

本実験で用いた頸管粘液除去器では, 粘液を効果的に 除去することが出来たのに対し，拡張棒では粘液が除去 されないばかりか，逆に子宮内に押し込んでしまうこと が考えられた。これは前者では，バルーンカテーテルに 目づまりする例がなく，スムーズに灌流できたのに対 し，後者ではバルーンカテーテルに目づまりが生じ，灌
流に支障を来たし，5例ではカテーテルの交換を余儀な くされたことで示唆される。また, 回収容器からの胚の 検索は回収後直ちに鏡検が可能であったことから，これ までの静置法（Elsden et al., 1976; Sreenan, 1978）に 比へてて胚の回収所要時間を 1 時間以上も短縮することが できた。このように本実験で用いた粘液除去器と胚回収 容器の併用は, ウシの胚回収のために極めて有効である と考えられた。

\section{References}

Elsden RP, Hasler JF, Seidel GE (Jr.) (1976) Nonsurgical recovery of bovine eggs. Theriogenology 6: $523-532$.

Suzuki T, Shimohira I (1986) Recovery of bovine embryos by new developed balloon catheter. Jpn J Anim Reprod 32: 42-43 (in Japanese).

Suzuki T, Suzuki M, Shimohira I, Fujiyama M (1984) An automatically flushing instrument of bovine's embryo. Jpn J Anim Reprod 30: 194-196 (in Japanese).

Sreenan JM (1978) Non-surgical egg recovery and transfer in the cow. Vet Rec 102: 58-60.

Whittingham DG (1971) Survival of mouse embryos after freezing and thawing. Nature (Lond) 223: $125-126$.

\section{要 約}

新しく考案した子宮頸管粘液除去器が胚回収前の頸管粘液除去に有効かどうかを検討した。泼は新 しく考案した胚回収シャーレ内に集めた。

新しい手法での胚の回収率は子宮頸管据張棒を用いたものよりも有意に高かった。すなわち回収さ れた胚の数は前者で $12.05 \pm 7.86$ ，後者で $8.52 \pm 6.8$ となった $(\mathrm{P}<0.05)$ 。頸管粘液除去のために 頸管拡張棒を用いた例では灌流障害が43頭中 5 頭にみられた。しかし新しく考案した子宮頸管粘液除 去器を用いた例では灌流障害はみられなかった。 